\title{
CUB and Sushi Domain-Containing Protein 3
}

National Cancer Institute

\section{Source}

National Cancer Institute. CUB and Sushi Domain-Containing Protein 3. NCI Thesaurus.

Code C143044.

CUB and sushi domain-containing protein 3 (3707 aa, $406 \mathrm{kDa}$ ) is encoded by the human CSMD3 gene. This protein plays a role in the development of neuronal projections. 